\author{
Mateusz Salwa \\ Institute of Philosophy, University of Warsaw; mateusz.salwa@uw.edu.pl \\ Sue Spaid \\ Independent scholar and curator; suespaid@gmail.com
}

\title{
THE AESTHETIC AND MATERIAL IMPLICATIONS OF ECOVENTIONS' ONGOING PARTICIPATORY DEMANDS
}

\begin{abstract}
In this paper, we assume that participatory art is an artwork, produced either collectively or by one artist, that invites participants to alter either its appearance, structure, and/or function, though not its purpose. This notion of audience participation is particular useful in discussing ecoventions (Sue Spaid's term). An ecovention is an "artist-initiated practical action with ecological intent" and its purpose concerns whatever issues the collective who originally implemented it aimed to address. Generally speaking, an ecovention's purpose concerns maximizing ecosystem functioning. We contend that such projects and various practices implied by them may result in an aesthetic experience of the environment based on the audience's feeling of participation in the ecosystem and. It is partly a consequence of the fact that ecoventions are artistic projects. We claim that ecoventions as participatory artworks are important because they expand the field of art by including environmental issues in it, offering a new model of audience participation and) they may effectively change for the better the ecological conditions of a particular place.
\end{abstract}

Keywords: Aesthetics, ecology, ecovention, environment, participation

\section{Introduction}

In recent years, philosophers have explored the complications arising from collaborative artworks that entail collective action, and thus result in co-authored artworks. ${ }^{1}$ Such works primarily involve the participation of multiple contributors of varying expertise, but they don't necessarily produce artworks that

1 S. Bacharach, D. Tollefsen, We Did It: From Mere Contributors to Coauthors, "Journal of Aesthetics and Art Criticism" 2010, vol. 68, no. 1, pp. 23-32; Collaborative Art in the TwentyFirst Century, ed. S. Bacharach, S.B. Fjaersted, J.N. Booth, Routledge, New York 2016. 
invite, let alone require, participation from contributors beyond the designated collective. Such collectives typically involve some combination of artists, designers, scientists, local politicians, curators, venue representatives, technicians, and members recruited from the public, who all join forces to produce some artwork that requires far more know-how, manual labor, legal permits, community support, and material resources than any number of artists could muster on their own. ${ }^{2}$ The most obvious co-authored artistic forms are film-making, theater, and dance, but since the 1970s, visual artists have increasingly worked this way.

In fact, what is these days known as "social sculpture" arose in the seventies as a form of collective action, organized to complete multi-layered tasks that proved far larger than any one artist could tackle on his/her lonesome. Even before Joseph Beuys first proposed the notion of soziale skulptur, American artists such as Agnes Denes, the Harrison Studio, Robert Morris, Dennis Oppenheim, Robert Smithson, and Alan Sonfist had collectively created large-scale works in the United States and the Netherlands. Five extant works, Denes' Tree Mountain (1992-1996/present), Sonfist's Time Landscape (19651978/present), Smithson's Broken Circle/Spiral Hill (1971-present) and Spiral Jetty (1970-present), and Morris' Observatorium (1971/1977-present) have since found institutional support. But as we shall see, this is the exception, and not the rule. Collectives typically recruit local stakeholders as members of the collective to care for the artworks, since the original collective typically dissolves, once its members move on to new projects. Being tied to some original collective, sometimes following several generations, stakeholder actions, as developed below, are more constrained than those heretofore associated with stewards, whose actions reflect personal knowledge and material resources.

In this paper, we aim to articulate a notion of audience participation that is particular to permanent ecoventions. Being living artworks, they require the recruiting of stakeholders to advance the artwork's purpose indefinitely. We contend that such projects and various practices related to them engender an aesthetic experience of the environment based on the audience's feeling of participation with the ecosystem. ${ }^{3}$ This reflects the fact that ecoventions are artworks, and artists (not only those producing ecoventions) are increasingly strategising ways to encourage public participation.

2 S. Spaid, Ecovention: Current Art to Transform Ecologies, Contemporary Arts Center, Cincinnati 2002, pp. 1-2.

3 M. Salwa, Gardens and the Aesthetics of Sustainability, in: Sustainable Art. Facing The Need For Regeneration, Responsibility And Relations, ed. A. Markowska, Taco, Warszawa-Torun 2015, pp. 105-111. 
An ecovention is an "artist-initiated practical action with ecological intent" and its purpose concerns whatever issues the collective who originally implemented it aimed to address. ${ }^{4}$ In 1999, curators Amy Lipton and Sue Spaid created the porte-manteau ecovention (ecology and invention) to distinguish land art that addresses ecological concerns. Generally speaking, an ecovention's purpose concerns maximizing ecosystem functioning, though the collective might specify the work's purpose, such as expanding urban forests, diverting and cleansing stormwater runoff, or alerting passersby to the significance of peat moss for carbon sequestration. An ecovention's "purpose" is not reducible to the artist's intentions, though like artistic reasons, collectives appeal to purposes to justify actions taken. One feature that is particular to ecoventions is that every artist, when introduced to an ecological issue, tends to identify a totally different underlying problem, and therefore a different approach to solving it, which demands assembling a particular collective to resolve the issue. Given the same site, one artist might point to a lack of biodiversity, another to the impact of nitrogen-rich agricultural runoff, and another to the dumping of manmade refuse that has seriously degraded the soil.

Ecovention stakeholders not only manage ecoventions, which like gardens are subject to nature's vicissitudes, but they assure that the artwork continues to fulfill its purpose, as identified by the collective, whose members left it in designated stakeholders' hands. Since most ecoventions are positioned outdoors, stakeholders fulfill several roles on behalf of some now, long-gone collective. On one hand, their role is on par with museum conservators who must make decisions on behalf of typically, long-gone artists; regarding how best to conserve their artworks. Alternatively, stakeholders are like gardeners whose practices reflect best practices for gardening management, which might lead them to make decisions that effectively alter the ecovention's appearance, structure, and/or function, so long as doing so incidentally preserves its purpose. The stakeholders may even decide that the ecovention is no longer needed or beyond restoration, and therefore opt to let it go back to nature.

As we shall see, the care required of ecoventions sometimes resembles that of artworks subject to technological innovation. When outmoded technologies cease to be commercially available, restorers typically substitute newer, more efficient versions, which risks changing their appearance, structure, and/ or function, though preserves their purposes intact. Consider Nam June Paik's video installation Time in Triangular (1993), whose 72 outmoded CRT TVs were replaced by 72 LED TVs. This not only increased the screen dimensions by $17 \%$, but modernized its structure, and made it function more efficiently, all

4 S. Spaid, Ecovention Europe: Art to Transform Ecologies, De Domijnen Hedendaagse, Sittard 2017, p. 35. 
the while preserving its original purpose as a video wall. Although conservation scholar Yuichiro Taira claims that such an extreme intervention has failed to maintain the work's identity, we view such extreme makeovers as not only likely for ecoventions, but possibly necessary in light of the changing science of ecological restoration, as well as a dynamic site's changing uses and inhabitants. ${ }^{5}$

As Mateusz Salwa has argued elsewhere, a garden's history is part of its identity, which is why garden conservators, following Alois Riegl's notion of "age value," rightly incorporate the traces of time into their restoration practices. ${ }^{6}$ Since ecoventions begin as artworks, Riegl's notion of historical value remains intact, so long as someone has registered its art historical significance. It doesn't make sense, however, to preserve an ecovention's age value, since one imagines the same site facing competing incursions over time, requiring its stakeholders to decide whether conserving the work or radically altering its appearance, structure, and/or function stands to maximise the well-being of the site's inhabitants. In some cases, stakeholders could decide that the environment has changed so much that it's time for artists to replace what remains with a brand new ecovention, whose purpose proves more appropriate. Like the octopus and squid, who only live long enough to reproduce, some ecoventions totally disappear into nature once they've achieved their purpose.

\section{Participatory Art}

Before offering claims that distinguish ecoventions from other types of participatory art, we want to clarify what we believe sets participatory art apart from most examples of visual art, and interactive art more specifically. As is well known, Marcel Duchamp maintained that the spectator "adds his contribution to the creative act". ${ }^{7}$ Even so, Duchamp only ever rarely invited anyone to touch his artworks, let alone experience the pleasure of spinning the wheel attached to the stool of Bicycle Wheel (1913/1950). ${ }^{8}$ One might expect that the singular artist who implored visitors to complete his works would have considered participation a form of completion, but clearly the "Don't Touch" Duchamp limited participation to interpretation. Moreover, had Duchamp insi-

5 Y. Taira, Conserving the Genes of the Arts in Japan, "Aesthetic Investigations" 2018 [forthcoming].

6 M. Salwa, The Aesthetics of Garden Conservation, "Aesthetic Investigations" 2018 [forthcoming].

7 M. Duchamp, The Writings of Marcel Duchamp, ed. Michel Sanouillet and Elmer Peterson, Da Capo Press, Boston 1989.

8 Walter Hopps told Sue Spaid that when Duchamp came to California for his 1963 retrospective at the Pasadena Museum of Art, Duchamp took a joyful tug on the wheel, but invited only Hopps to do so. 
sted that museums exhibit "an exhibition copy," so that every visitor could give a massive tug on the wheel, Bicycle Wheel would still be only interactive (it's appearance never changes), and would fail as an example of participatory art. We thus offer the following definition of participatory art:

Participatory art is an artwork, produced either collectively or by one artist, that invites participants to alter its appearance, structure, and/or function, though not its purpose.

With this definition we would like to achieve three goals. First, we want to put more stress on the way audiences physically engage ecoventions (otherwise they will cease to exist) than on the interactive aspect of a work of art, which primarily belongs to its conceptual scheme or scenario (whether its audience will in fact interact with it or not is irrelevant in terms of the existence of the work and its comprehensibility). ${ }^{9}$ Second, we distinguish the sense of the term 'participatory' that we apply to ecoventions from other uses of the term, e.g. those associated with relational aesthetics. ${ }^{10}$ Third, we don't simply replace the more common notion of "artist's intention" with "artwork's purpose." Rather we use the word purpose here, like above, to show that there is something integral to the work, so that a participatory artwork cannot become "anything." Each participatory artwork's purpose constrains the kinds of options afforded its participants, in order to avoid annihilation. Being open systems, such artworks are unfinished, elastic, and irreversible. ${ }^{11}$

Consider Maura Bendett's Eleven Balls (1990), a nascent example of participatory art. With Eleven Balls, museum visitors found a 1,85m high mound of eleven, colourful papier-mâché balls, each filled with BBs and about the size of a large beach ball, such that holding one at chest height would block one's vision. ${ }^{12}$ While the most one can do here is: unstack the balls, shake one, and then re-stack the mound, doing so visibly alters the artwork's appearance, struc-

9 R. Kluszczyński, Sztuka interaktywna: od dzieła - instrumentu do interaktywnego spektaklu, WAiP, Warszawa 2010.

10 Cfr. N. Bourriaud, Relational Aesthetics, Les presses du réel, Dijon 2002; C. Bishop, Artificial Hells: Participatory Art and the Politics of Spectatorship, Verso, London 2012.

11 S. Spaid, Open Systems: Incompleteness, Participation, and Elasticity. Exhibition Brochure, Santa Monica Museum of Art, Santa Monica 1995.

12 Maura Bendett's Eleven Balls (1999) was included in "Action Station: Exploring Open Systems" (1995), curated by Sue Spaid for the Santa Monica Museum of Art, Santa Monica, United States. "Action Station" was the first museum exhibition to focus exclusively on participatory art. Tom Finkelpearl's "Engaging Objects: The Participatory Art of Mirrors, Mechanisms, and Shelters" (1986) featured what we describe as interactive works, since participants couldn't alter their appearance, function or structure. 
ture (rolling on the floor instead of stacked in the corner), and function (making sounds or not), though not its purpose. Simply put, Eleven Balls' purpose is to invite visitors to make sounds, while reordering its components. With this in mind, visitors who steal balls, saw some in half, or crack one on the floor like an egg destroy the work, though not because they've changed its appearance (fewer balls), structure (sawing and unstacking weaken all the same), or function (silent). Much like a painting with cracking on its surface, participatory art is considered "destroyed" when someone decides that the work no longer fulfills its purpose. In fact, the museum (on advice from the artist) might consider it fine with eight or five balls remaining, but when it can no longer be stacked or shook, "game over;" which explains why museums rarely present participatory works as artists intended them to be experienced. ${ }^{13}$

One begins to see how the activities of ecovention stakeholders, whose participation is crucial for an ecovention's long-term success, bear greater resemblance to those of participatory-art participants than to those of art conservators. Ecovention stakeholders are first and foremost the appreciators of some local ecovention, and are thus the ecovention's intended audience. Having been personally transformed by the work, stakeholders act on behalf of some collective to ensure that such works remain intact for future stakeholders. One could say that ecovention stakeholders subsume responsibilities normally undertaken by art institutions on behalf of works in their collection. Before developing the implications for ecoventions on aesthetics, we explore six European ecoventions in greater detail, so as to grasp the range of participation initiated by such works.

\section{Six Case Studies}

To explore the range of participation generated by ecoventions, we've selected six ongoing projects. Over time, these works' appearances, structures, and functions undergo dramatic changes. However, most have scales too monumental to warrant a physical engagement on par with Eleven Balls, described above. As already noted, artists implementing ecoventions in the seventies were among the first to work collectively, so it is no surprise that during the nineties, most artists producing ecoventions initiated "copyleft" principles, such that they not only gave users permission to implement their ideas elsewhere, but they actually hoped that users would do so. This makes ecoventions more like "one-off" prototypes, meant to be emulated and customized for use anywhere, than "fail-safe" models to be copied and manufactured for commercial distri-

13 Children's museums whose interactive works undergo routine destruction must also consider the work's original purpose when deciding how best to maintain/restore said works. 
bution. Ecoventions not only prove invaluable vehicles for knowledge sharing regarding one's immediate environment, but they prove remarkably generative. Even those that were initially site-specific artworks have since inspired ecologists to adopt their approaches. ${ }^{14}$

1). Thousands have trekked to the peak of Agnes Denes' Tree Mountain-A Living Time Capsule -11,000 Trees, 11,000 People, 400 Years (1992-1996/ present) in Ylöjarvi, Finland. As its title implies, 11,000 people (some living abroad) each received inheritable certificates committing them and twenty future generations (220,000 people more) to protect this massive pineapple-like hill $(420$ x 270 x 28m) over the 400-year lifespan of 11,000 Finnish Pine Trees (Pinus silvestris). Because each tree grows at a different rate and some will die, it risks to lose its unique form, leaving certificate heirs to decide how best to manage its changed appearance, structure, and function, without altering its purpose. Situated atop an aquifer, the local community originally commission this ecovention to block this site's future development, thus ensuring the groundwater's purity for generations to come..$^{15}$

2) In 1997, one year before the Open Source Initiative was launched, N55 started availing Manuals (42 to date) for building ecologically friendly homes, greenhouses, houseboats, trucks, vehicles, indoor farms, portable fish farms, clean air machines, shops, cairns, solar power, walking houses, and spontaneous public space on its website, n55.dk. ${ }^{16}$ All that N55 demand from users who follow their manuals' step-by-step "how-to-instructions" is that they credit N55's design. High school students and retirees across the globe have constructed N55 prototypes from scratch.

3) The very same year, George Steinmann initiated and carried out dozens of actions, comprising Komi-A Growing Sculpture, 1997-2006, with hundreds of local residents inhabiting Europe's largest boreal forest in the Ural Mountains of Russia's northeast Komi Republic. Realising that this region was at risk for extreme environmental degradation, owing to its oil and metal reserves, coupled with coal mining, petroleum and timber industries; Steinmann took it upon himself to propose a Centre for Sustainable Forestry. During the decade he spent developing this centre, he worked alongisde local inhabitants, forestry specialists, and various Swiss development agencies to develop "strategies to protect Komi's natural resources against further exploitation and identif[y] sustainable methods for developing natural resource management, resulting in a work of art" ${ }^{17}$ In 2007, he officially transferred this project to the Russian

14 S. Spaid, Ecovention Europe...

15 Ibid., p. 160.

16 Ibid., p. 127.

17 Ibid., p. 53. 
government, which not only manages the "Priluzje" Model Forest project that Steinmann initiated, but its success at profitably harvesting timber carrying "FSC forest-management certification" led the Russian government to expand this programme to neighboring Arkhangelsk and Kirov regions..$^{18}$ In this case, even the Russian foresters vying for FSC certification have become unwitting participants in Steinmann's art.

4) For Veden Taika (The Magic of Water) (2007-2009/present), Jackie Brookner worked with "local volunteers, regional science experts, the students and faculty of Salo Polytechnic Institute, the Salo Parks Department and Office of Environmental Protection, the EcoVillage Institute, and artist Tuula Nikulainen." 19 This collective constructed three artificial islands (one for nesting black-headed gulls and two for cleaning the water), thus transforming a former sewage lagoon in Salo, Finland into healthy habitat for migrating birds. ${ }^{20}$ Scientists continue to monitor Veden Taika to evaluate its success and birdwatchers gather monthly to catch glimpses of rare species in what is billed as "the best bird-watching in Southwest Finland." Most important volunteers convene routine restoration events alongside city workers (paid for by the City of Salo) in order to maintain Veden Taika. ${ }^{21}$ The artist's premature death makes stakeholders responsible for many decisions, such as how/whether to replace a mechanical mister that regularly stops working, soon after it has been fixed. Similarly, when the adjacent wastewater treatment plant got a new boss, the stakeholders met with him to confirm their role in maintaining the ecovention.

5) As part of his Cosmopolitan Chicken Project (since 1999,) Koen Vanmechelen has cross-bred over 20 different breeds of chickens, with each new strain producing a chicken whose DNA sequencing is considerably longer, which theoretically indicates their greater immunity against diseases and thus the breed's resistance to species depletion..$^{22}$ Although his videos and photographs regularly feature ordinary folks, only collectors and museum representatives tending to the needs of exhibited CCP exemplars, temporarily housed in chicken coops, had ever really participated. In 2017, Vanmechelen pushed this project further, inviting ten interested citizen scientists for a DNA test, so that each participant could be paired with the most appropriate strain. The citizen scientists signed contracts committing them to a three-month, minimum term and to documen-

18 Ibid., p. 55.

19 http://www.schuylkillcenter.org/art/?page_id=284; accessed June 25, 2018.

20 https://www.sll.fi/varsinais-suomi/paikallisyhdistykset/salo/kevatlinturetki; accessed June $25,2018$.

21 http://vedentaika.blogspot.com/; accessed June 25, 2018; Email correspondence with Tuula Nikulainen dated June 25, 2018; https://www.sll.fi/varsinais-suomi/paikallisyhdistykset/ salo/halikonlahden-kevatlinturetki; accessed June 25, 2018.

22 S. Spaid, Ecovention Europe..., pp. 118-119. 
ting their relationship with their foster pet, information that Vanmechelen imagines will help him to expand this project's participatory aspects.

6) Since 2012, Cecylia Malik has collaborated with dozens of artists to organise Critical Water Mass (since 2012), an annual Kraków-wide float on the Wisła, the $1000+\mathrm{km}$ river that longitudinally traverses Polska from the Bieszczady mountains to the Bay of Gdańsk on the Baltic Sea. The seventh edition took place on 24 June 2018. Organized for the most part by six friends, Malik works alongside Małgorzata Nieciecka-Mac, Piotrek Dziueszia, Bartolomeo Koczenasz, Jakub Wesołowski and Martyna Niedośpial, who help participants build their rafts in an open-air studio (the "shipyard") for two weeks before the event. Those who don't build rafts come with their kayaks, canoes, traditional boats, and whatever else floats. It's really the only time each year that anyone other than tourists experience being on the river. And unlike tourists, the people get to touch the water. No wonder this event, which weds community, art, and sport to ecology attracts 200 people each year. Just as Critical Mass, the mass bicycle ride that has been spreading across the world since 1992, one imagines Critical Water Mass one day criss-crossing the planet's rivers.

These projects vary in numbers of potential participants, from a handful of local residents, scientists, and bird watchers restoring Brookner's islands to upwards of potentially 230,000 committed stakeholders protecting Denes' Tree Mountain to growing numbers of people taking part in Malik's annual float, Vanmechelen's chicken adoption program, Steinmann's forest conservation scheme, or N55's online instructions. Like a multiplication dance that begins with two dancers, yet swells to 100 as dancers invite new partners; ecoventions not only employ living materials that grow, but as more and more people are recruited into their orbits, their influences grow, and people find new applications elsewhere. It's no wonder Steinmann calls his art growing sculptures.

Ecoventions are thus distinguishable from most participatory art, since they not only engender a multiplier effect, but they engage people in long-term projects. Moreover, the public's interest in their success effectively transports these inventive practices, which users often apply in myriad circumstances, beyond original audiences and academia, and across continents (often via the Internet). The fact that people elsewhere can find new applications makes the virtual transmission of ecoventions significant, a feature that is not necessarily true for participatory works focused on the present (the "here and now," rather than the "there and later").

\section{Ecoventions and Aesthetics}

Ecoventions are to be regarded and - more importantly - practiced as processes whose trajectory is defined by how they may be, and in fact are ada- 
pted to changing environmental conditions, as well as to stakeholders' views and interests. Nevertheless, what remains intact is not only their ecological purpose, but also their artistic character. Even though stakeholders may depart from the artist's intentions in their practices and views, they still participate in maintaining an ecovention as an artwork. As such, ecoventions are subject to aesthetic appreciation. Overcoming aesthetic intentionalism doesn't amount to aesthetic subjectivism. It rather makes room for object-oriented approaches. This has at least two ramifications. First, as ecoventions are ecological, they offer an aesthetic experience that differs from those had in front of 'traditional' works of art, be it painting, dance or even interactive installations. Second, given the participatory character of ecoventions, the aesthetic experiences that they engender are similarly participatory. That is, experiencing an ecovention aesthetically amounts to being engaged in and with it as a material object or site. The following passages are meant to develop this view further.

As the above case studies demonstrate, ecoventions vary greatly in character. Some are directly rooted in the land art tradition and many have a science $\&$ art focus, but all could be described as activism. Others still, seem to have nothing to do with art except for the fact that artists invented them. All this makes ecoventions particular not just because of their ecological intent (still outside of today's artistic mainstream), but because they spill over into fields that are not artistic, per se. As such they doubly expand the field of art: they introduce environmental issues to art audiences, while inviting audiences to experience art in non-art spaces such as fields and ponds. These two aspects go hand in hand and are grasped in the definition of an ecovention offered in the introduction (an 'artist-initiated practical actions with ecological intent'), enabling ecoventions to be distinguished from other kinds of art exhibiting ecological content. By entering the environment beyond the art world, contrary to art projects intended for galleries, they are aimed not at interpreting reality, but at effectively changing it. ${ }^{23}$

More often than not, ecoventions are - at least prima facie - very dissimilar from ecological artworks exhibited in galleries, especially since galleries currently seem bent on showcasing 'catastrophe art'. On the other hand, it seems challenging to distinguish them from 'mere real' practical actions with ecological intent by focusing exclusively on their look or function, but this hardly undermines their status as art, given Arthur Danto's philosophical work inspired by Pop Art. ${ }^{24}$ Ecoventions' status as art is not derived from the fact that artists make them or art critics and curators treat them as art, but their inventiveness. ${ }^{25}$ In terms of

23 Ibid., pp. 17-22.

24 A. C. Danto, The Transfiguration of the Commonplace, Harvard University Press, Cambridge 1981.

25 S. Spaid, Ecovention: Current Art..., p. 3. 
ecological intent, a project's status as art may seem to be of little importance. Does it make any difference whether a practical action, e.g. counting malformed amphibians in Dutch ponds, creating a compelling composting system, or planting a social garden is carried out by an artist, a scientist, or a social worker, so long as it proves efficient in promoting ecological health? And in fact, it does, because to count as art, the artist must invent something new that also works. And since the artist's 'art' is at stake, and therefore his/her career, he/she will tap artworld and community resources, as well as mechanisms for fundraising, publicising, and sharing knowledge in ways that other professions lack access. For these reasons, one cannot describe the context for ecoventions in sociological or institutional terms, or solely in terms of ecological performance. More importantly, however, being artworks ecoventions are objects of aesthetic appreciation. What then differentiates ecoventions from similar no$\mathrm{n}$-artistic projects is that aesthetic appreciation is a necessary aspect of their reception on behalf of the public. Needless to say, non-artistic projects may also be aesthetically appreciated, but in terms of what they are and what they aim to achieve, the aesthetic appreciation is contingent, such that its lack does not amount to their failure. Like all ecological artworks, ecoventions require an aesthetic response from the public in the sense that if they manage to realise the 'ecological intent' but do not trigger an aesthetic appreciation (experience) they fail as artworks. Of course, the aesthetic experiences and appreciation that ecoventions afford audiences differ markedly from those engendered more generally by artworks, including many ecological ones.

Aesthetic appreciation is understood here as valuing a work of art for its aesthetic values, which demands establishing what kind of aesthetic values it has and why, how they are related to other values etc. Given that ecoventions are only initiated by an artist and therein maintained or kept alive by the public and that they are materially immersed in their natural and social environment, the sort of aesthetic appreciation required by ecoventions is different from one rooted in a sharp division between art and life.

As it is impossible to appreciate an ecovention without taking into account the environment in which it is situated, ecoventions thus foster an aesthetic appreciation of the environment. ${ }^{26}$ The art-centered aesthetic appreciation (focused on the artistic status of the work) is thus broadened by an approach that seriously considers the fact that what is aesthetically appreciated is nature. It may be said that ecoventions are artworks that make people focus on ecological issues and act accordingly by promoting, among other things, environmental aesthetic experiences.

26 The term 'environment' here is understood as synonymous with 'nature'. 
Aesthetic experience and appreciation of the environment have been comprehensively discussed in the aesthetics literature. The approach known generally as environmental aesthetics also proves useful for gaining insight into the aesthetic implications of ecoventions. ${ }^{27}$ In his oft quoted article, Ronald Hepburn criticized contemporary Western culture more than half a century ago (more or less around the same time ecological art was born) for neglecting natural beauty. ${ }^{28}$ Despite the broad interest in nature, he noticed that nature was conceived of as a mere reflection of artistic beauty, and as such was deemed unworthy of serious consideration. Hepburn's aim was to rehabilitate it for philosophical discussion. To do so, he demonstrated that the aesthetic experience of nature has a different character than the aesthetic experience of art. He thus strongly opposed the traditional view that reduced aesthetic experience to the realm of art and claimed that nature too has aesthetic values, so far as it has properties resembling those of artworks. Hepburn thus introduced the way to characterise aesthetic experiences of nature.

Hepburn noticed above all that when people experience nature, they are surrounded by nature and not before it, as is the case with most artworks. People are then perforce engaged in and with nature and as a result they experience themselves immersed in it, i.e. they experience themselves as being in nature and part of it. Such experiences can be, however, accompanied by feelings of detachment. Contrary to an aesthetic experience of a work of art, he noticed that when one has an aesthetic experience of nature, it is impossible to separate the experienced objects or processes from their surroundings (environment). As a result, it is impossible to decide what should and should not be included in the experience. Hence, the aesthetic experience of nature is rather blurry, but at the same time, it is not fixed and may change. Finally, he contended that the aesthetic experience of nature is shaped by people's awareness of what they are experiencing, that is, nature. When we know that what we are experiencing is a natural 'object', we can figure out which natural causes have brought it forth and made it to be such and such. According to Hepburn, such knowledge is not an extra-aesthetic filter imposed on the experience, but an inherent factor that determines the aesthetic experience 'from within'. The aesthetic experience is thus always an experience of an 'object,' interpreted in a particular way.

27 There are other approaches, too, e.g. G. Böhme, Für eine ökologische Naturästhetik, Suhrkamp, Frankfurt am Mein 1992; P. D’Angelo, Estetica della natura: bellezza naturale, paesaggio, arte ambientale, Laterza, Roma 2010; M. Gołaszewska, Święto wiosny: ekoestetyka nauka o pięknie natury, Universitas, Kraków 2000; M. Seel, Eine Ästhetik der Natur, Suhrkamp, Frankfurt am Mein 2009. Philosophy, ed. B. Williams, A. Montefiore, Routledge \& K. Paul, London 1966, pp. 285-310. 
Therefore, even if the aesthetic experience is primarily focused on aesthetic (sensual) aspects of 'objects,' it necessarily involves extra-perceptual elements such as knowledge, the imagination, associations, desires etc. which, however, do not dominate its sensual dimension. It is of crucial importance for Hepburn that the aesthetic experience of nature be an experience of nature as it truly is. The idea that nature should be aesthetically experienced and appreciated 'on its own terms' is the main topic within environmental aesthetics. ${ }^{29}$

It is beyond the scope of the present article to discuss various perspectives on environmental aesthetics. Suffice it to say that positions may be generally divided into two groups. Some exponents opt for a cognitive approach, claiming that aesthetic experience requires some kind of knowledge about the experienced 'object', while others contend that aesthetic experience is mainly bodily. The theories of Allen Carlson and Arnold Berleant epitomize these two lines of argument, respectively.

Having criticized 'art-centered,' traditional approaches to the aesthetic appreciation of the environment, according to which one appreciates nature formally, and in a context-free way, Carlson suggested another approach. ${ }^{30}$ Taking as his starting point Kendall Walton's theory that in order to appreciate art one has to have a set of categories that adequately describe what one is appreciating, in other words, one has to know what the object of appreciation is, Carlson claimed that in order to aesthetically appreciate an environment one has to refer to categories that fit it. Such categories are mainly offered by the natural sciences, but some are borrowed from everyday knowledge, too.

Carlson's theory has been put to various criticisms. He was accused of expounding a reductionist view, which excluded factors that also shape people's view of their environments such as emotions, imagination, cultural imagery, etc. ${ }^{31}$ Nevertheless, the idea that the environment is to be aesthetically experienced and appreciated in a way that does not consist of imposing on it preferences and clichés rooted in one's artistic taste has not been questioned. Even if it is highly debatable what it means to experience and appreciate environments 'on their own terms,' it is crucial to attempt to do so, which in fact amounts to constantly looking for categories that fit the experienced and appreciated environment.

Searching for such categories offered by various academic disciplines as well as extra-academic cultural practices and applying them to environments

29 Y. Saito, Appreciating Nature on Its Own Terms, "Environmental Ethics” 1998, vol. 20, no. 2, pp. 135-149.

30 A. Carlson, Aesthetics and the Environment. The Appreciation of Nature, Art and Architecture, Routledge, New York 2000.

31 The Aesthetics of Natural Environments, ed. A. Berleant, A. Carlson, Broadview Press, Peterborough 2004. 
results in their being interpreted in numerous ways. Thinking of aesthetic experience and appreciation of the environment in hermeneutical terms has two ramifications. ${ }^{32}$ First, conceiving of the environment as subject to interpretations does not mean that every interpretation is valid. On the contrary, it means that some interpretations qualify as misinterpretations and thus ought to be avoided. Second, various interpretations prove contradictory, which - given that these interpretations may lead to contradictory actions involving the environment - is a serious practical problem with great ecological consequences.

While it is fairly simple - with some exceptions - to dismiss misinterpretations within academic disciplines that have well-established categories, it is not so whenever cultural practices are at stake, since these are often based in categories that are not generally agreed upon. It is also in the sphere of cultural practices that major contradictions arise. One way to cope with misinterpretations and interpretational contradictions is to show that they are based on certain categories that - in case of the former - are wrong and - in the case of the latter - may be changed.

In the past two years, there has been a much heated multi-lateral debate on how to manage the forest of Białowieża, which was invaded by spruce bark beetle (Ips Typographus). The bone of contention has been how to interpret the multiplied presence of the bark beetle in the forest. On the one hand, it was said to be unnatural and pose a threat to the vegetal life, which would justify the felling and removal of huge quantities of infected trees. On the other hand, it was described as a natural process typical of this kind of forest and it was claimed that no means against it should be used, because felled trees serve as nurse logs that generate healthier, more biodiverse forests. While such discussions usually take place among specialists in ecology, this conflict generated an accompanying debate among ecologists, foresters, and inhabitants of the region over whether to consider the forest natural or only a partly-natural environment. Here contradictory interpretations violently met. Ecologists contended that it was natural, and would generate more stands in the long-run, and was hence worthy of protection, while foresters claimed that it was a long-cultivated environment, whose main worth stemmed from the amount of lumber produced for industrial use, and inhabitants praised the forest for its touristic values. As an aside, it may be said that such varying perspectives no doubt influence different aesthetic experiences and appreciations of Białowieża, even if the opponents never mention the forest's aesthetic value.

32 Interpreting Nature: The Emerging Field of Environmental Hermeneutics, ed. F. Clingerman, B. Treanor, M. Drenthen, D. Utsler, Fordham University Press, New York 2013; Environmental Aesthetics: Crossing Divides and Breaking Ground, ed. M. Drenthen, J. Keulartz, Fordham University Press, New York 2014. 
The ecological clash of interpretations has been solved - the felling has been stopped, which may be seen as an act that acknowledges the legitimacy of pro-natural interpretation of the beetle's activity. Yet, the other views mentioned above are too disparate to be unified. What is more, neither of them can in fact be dismissed as they are all justified. It does not mean, however, that this controversy cannot be solved. A good solution would be to mediate between them in such a way as to reconcile them to the highest possible degree. ${ }^{33}$ This would require that all of the parties involved should be ready to broaden their views of the forest by at least recognizing other perspectives. Even if one aesthetically appreciates an environment in terms of its industrial potential, one can still recognize that someone else appreciates it for its ecological values and vice versa.

The debate over the 'sanitary' measures in Bialowieża coincided with promulgating the infamous law permitting the felling of trees without permits on private property. In reaction to this, Cecylia Malik, mentioned above, launched a nationwide protest Matki Polki na Wyrębie (Polish Mothers of the Felling) (2017). One resulting photograph shows Malik and other mothers breastfeeding their children, while seated on tree trunks left after city trees were unnecessarily felled. By posting their picture on the Internet, she initiated a social-media action inviting other mothers to shoot and post similar pictures across Polish cities. It was one of the most important and well-known artistic commentaries on environmental issues, offering yet another interpretation of nature, namely as a good that must be protected and cared for by our generation for all to come.

Polish Mothers... shows a landscape which no one would aesthetically appreciate in a positive way. Malik's work directs one's attention to the aesthetic values of a post-forest environment by showing it as its principal subject. Because the photograph is an artwork, itis appreciated in aesthetic terms. The women are colorfully dressed, which contrasts them with the sad brownish greyness of the background - this trick underlines the poor ecological condition of the site behind the women, but at the same makes the picture visually appealing. Polish Mothers... owes its impact as much to its message as to its aesthetics.

Although Malik's original action was an ecovention, the ensuing photographs are rather ecological artworks. Still, the roles for aesthetic experience and appreciation of it are similar to those for ecoventions. The difference of course is that the photograph requires solely an art-centered experience and appreciation.

As 'practical actions with an ecological intent,' ecoventions result from certain interpretations of nature and its interests. A successful ecovention achieves

33 J. Van Buren, Environmental Hermeneutics. Deep in the Forest, in: Interpreting Nature: The Emerging Field of Environmental Hermeneutics, ed. F. Clingerman, B. Treanor, M. Drenthen, D. Utsler, Fordham University Press, New York 2013, pp. 17-35. 
its intended ecological benefits, but at the same time it makes people involved in it aware of the particular interpretation that originated it and influenced its outcome. Stakeholders thus grasp that such interpretations may change over time, e.g. since realizing an artwork's purpose requires constant adjustment of methods to new conditions. Having ecological aims, ecoventions not only belong to their natural environment, but they belong to social communities, which means that they occupy a place where the interests of nature and society, which usually sharply differ, intersect.

Even if ecoventions are meant to serve nature, or its remnants in otherwise humanized landscapes, they are fully human enterprises, very often requiring their initiators and participating public to exhibit particular skills, diligence, as well as access to highly -sophisticated technologies. That said, it is obvious that ecoventions are based on interactions - participating in them amounts to nothing else than 'doing things,' or electing not, in and with nature. What they promote then is a particular way of doing that is based on the belief that nature - be it a forest, a river, or a chicken - deserves respect and care no matter its actual or possible use. In other words ecoventions foster an approach that is eager to accept new interpretations of nature, provided that they are based on the assumption that nature is to be taken care of (which is in fact an interpretation, too).

The success of an ecovention is measured not only by the degree of its ecological impact, but also by the extent to which it has inspired people to change their views of nature. The more that people participate, the more likely the ecovention will modify their views and the more successful it will be. The measure of its success is then the degree of its endurance, achievement of its goal, as well as its influence on participants and passersby, also on public art.

According to environmental aesthetics, one's understanding of the 'object' changes one's aesthetic experience and appreciation. If ecoventions manage to change their public's' views, then they change the public's aesthetic experience and appreciation of nature. It is no longer experienced and appreciated according to aesthetic clichés. What might otherwise be stereotypically deemed ugly or aesthetically inappropriate could be experienced as aesthetically positive thanks to views fostered by an ecovention. This effect is backed by the fact the ecoventions themselves are aesthetically appreciated by people who participate in them. Had they not been, no one would have engaged them in the first place. Who would elect to take care of pine trees in Finland or chickens in Belgium without first admiring the artist's idea and then realizing the potential of his/ her responsibility and duties? Who would opt to paddle down Wisła without thinking it is great to try to experience a river in this way? The artistic status of ecoventions focuses people's attention on their aesthetic values, which in turn 
redirects it towards aesthetic values of nature involved in these projects. The moment of the switch is the moment when art-centered aesthetic experience is broadened and turns into a nature-centered one.

As mentioned above, there is a second, non-cognitive way of developing environmental aesthetics. Its best-known exponent is Arnold Berleant, whose views are worth mentioning since they complement what has already been said. ${ }^{34}$ Following John Dewey's philosophy of experience on one hand, and phenomenology on the other, he claimed that aesthetic experience of environment is a bodily experience of being united with one's surroundings. It is a feeling of continuity between the Self and the environment, which amounts to the feeling of engagement. He criticises the traditional account of what it means to aesthetically experience an environment, and recommends replacing its experience of detachment with a primordial experience of belonging. What is more, he contends that the traditional notion of aesthetic experience as "detached" is entirely mistaken, not only when nature is at stake, but also in reference to art (as is proved by, among other things, participatory art). One of the consequences of the traditional approach is the belief that humankind is not part of nature, which has unfortunately encouraged people to treat nature instrumentally. For Berleant, an aesthetic experience is engendered whenever one is immersed in one's environment, as for example when one is going down a river in a canoe and feels a sort of unity that embraces the canoers and world around.

Given that ecoventions are participatory artworks in the sense that they require material actions on behalf of their public, they invite people to participate not only in the artist's project, but also in nature. As an aside it may be said that this double participation requires a constant reinterpretation of the project and of the environment. Such actions as creating habitat for migrating birds and then observing them year after year, for centuries to come, amount to being engaged with the object of one's actions. Again, this sort of engagement is aesthetically appreciated in a positive way, and often by people who never previously imagined engaging nature in the way the ecovention requests. Ecoventions thus dare people to appreciate unfamiliar aesthetic experiences, including the most bodily ones

Ecoventions - at least the successful ones - may then be said to engender cognitive and non-cognitive aesthetic experiences of nature, which makes people change the way they experience nature 'outside' the ecoventions in which they have been involved.

34 A. Berleant, The Aesthetics of Environment, Temple University Press, Philadelphia 1992. 


\section{Conclusions}

Although Ecoventions have been more and more numerous in recent years, and are an important type of ecological art, they still occupy a place on the border of mainstream art after nearly 60 years. Ecoventions thus belong to a movement that outlasted Cubism, Constructivism, Abstract Expressionism and many others. During that time they have reflected the changes within the art world and outside of it. On many occasions they have proven to be the real avant-garde in both art and ecology.

They are noteworthy for at least three reasons. (1) They have beneficial effects for the ecosystems for which they were created. The solutions or schemes developed by collectives may very well be used in other places and by people other than those participating in them. Their impact is warranted by the fact that they are science-based. Had it not been for their 'scientific' character, ecoventions would be little more than an expression of collective good will on behalf of their creators and participants. At the same time, being artworks, ecoventions have much broader goals than the sciences with which they share epistemic goals. And in many respects, ecoventions are much more sensitive to social issues. Not only must they improve the conditions of a particular ecosystem, but they are also meant to change people's views and attitudes. They achieve the latter by engendering new aesthetic experiences, as art does. They do so by conveying various reasons for aesthetically appreciating the environment in a positive way, even 'unscenic' ones. ${ }^{35}$

What is needed is another set of categories for the aesthetic experience and these are offered by ecology as a science that provides a particular interpretational frame. In this sense, the impact of many ecoventions reaches beyond particular circumstances in which they were designed. Ecoventions thus (2) expand the field of art by including environmental issues in it and offer a model of art that is supposed to transform the world, not only its natural side, but also its social features. As such they also offer a model of audience participation that is generative. The participants are not only responsible for 'making it happen' by filling out the conceptual scheme designed by the artist, but also for reinterpreting and adjusting it to the ever-changing conditions that ecoventions are supposed to accommodate. The public for ecoventions co-authorizes them to a much greater extent than is necessary for other sorts of interactive or participatory art. (3) The participatory aspect of ecoventions is crucial for their success. In fact, absent participation, they cease to exist. More-

35 Y. Saito, The Aesthetics of Unscenic Nature, "The Journal of Aesthetics and Art Criticism" 1998 , vol. 56, no. 2, pp. 101-111. 
over, participation is the best way to inspire someone to change her/his views. Unlike scientific experiments in the lab or on land, everyone is a welcome to participate in an ecovention. As such, ecoventions may be the most effective way to change the world. This sort of participation - as mentioned above - is creative. One participates in an inventive project, but at the same time one must be inventive. This double inventiveness enhances participants' capabilities, improving their capacity to enhance other aspects of their lives. ${ }^{36}$ By interpreting an ecovention and its circumstance, participants effectively create new realities and situations that transform reality. The participatory character of ecoventions guarantees their performativity.

Ecoventions are a powerful artistic tool that aims to change the world for better, bit by bit, step by step; even generation by generation. They may change it in vivo by changing the environmental sensitivity of people who participate in them. The ultimate lesson offered by ecoventions is that we all - even when we do not participate in any particular ecovention - do participate in the environment, whether we like it or not.

\section{BIBLIOGRAPHY}

Bacharach, Sondra and Deborah Tollefsen (2010) We Did It: From Mere Contributors to Coauthors, "Journal of Aesthetics and Art Criticism", vol. 68, no. 1, pp. 23-32.

Bacharach, Sondra, Siv. B. Fjaersted, and Jeremy Neil Booth, eds. (2016) Collaborative Art in the Twenty - First Century, New York: Routledge.

Berleant, Arnold (1992) The Aesthetics of Environment, Philadelphia: Temple University Press.

Berleant, Arnold and Allen Carlson, eds. (2004) The Aesthetics of Natural Environments, Peterborough: Broadview Press.

Bishop, Claire (2012) Artificial Hells: Participatory Art and the Politics of Spectatorship, London: Verso.

Böhme, Gernot (1989) Für eine ökologische Naturästhetik, Frankfurt am Mein: Suhrkamp.

Bourriaud, Nicolas (2002) Relational Aesthetics, Dijon: Les presses du reel.

Carlson Allen (2010) Aesthetics and the Environment. The Appreciation of Nature, Art and Architecture, New York: Routledge.

36 Although most ecoventions are candidates for Tania Brugera's Museum of Arte Útil, whose focus is "useful art," we rather identify ecoventions as "practical art." 1) Since all art is useful to somebody, whether collectors or politicians; useful art risks abuse. 2) Useful art engenders users of "artistic competence," while practical art invites participants to produce artworks that compound participants' capacities and capabilities. 3) Practical art is generative, as it transforms today's actor-recipients into tomorrow's actor-producers. 
Clingerman, Forrest, Treanor, Brian, Drenthen, Mike, Utsler, David, eds. (2013) Interpreting Nature: The Emerging Field of Environmental Hermeneutics, New York: Fordham University Press.

D’Angelo, Paolo (2010) Estetica della natura : bellezza naturale, paesaggio, arte ambientale, Roma: Laterza.

Danto, Arthur C. (1981) The Transfiguration of the Commonplace, Cambridge: Harvard University Press.

Drenthen, Mike and Josef Keulartz, eds. (2014) Environmental Aesthetics: Crossing Divides and Breaking Ground, New York: Fordham University Press.

Sanouillet, Michel and Peterson, Elmer, eds. (1989) The Writings of Marcel Duchamp, Boston: Da Capo Press.

Gołaszewska, Maria (2000) Sěwięto wiosny: ekoestetyka nauka o pięknie natury, Kraków: Universitas.

Hepburn, Ronald (1966) Contemporary Aesthetics and the Neglect of Natural Beauty, [in:] B. Williams, A. Montefiore, eds., British Analytical Philosophy, ed. B. Williams, A. Montefiore, London: Routledge \& K. Paul, pp. 285-310.

Kluszczyński, Ryszard (2010) Sztuka interaktywna: od dzieła - instrumentu do interaktywnego spektaklu, Warszawa: WAiP.

Saito, Yuriko (1998a) Appreciating Nature on Its Own Terms, "Environmental Ethics", vol. 20, no. 2, pp. 135-149.

Saito, Yuriko (1998b) The Aesthetics of Unscenic Nature, "The Journal of Aesthetics and Art Criticism”, vol. 56, no. 2, pp. 101-111.

Salwa, Mateusz (2015) Gardens and the Aesthetics of Sustainability, [in:] A. Markowska, ed., Sustainable Art. Facing The Need For Regeneration, Responsibility And Relations, Warszawa Torun: Taco, pp. 105-111.

Salwa, Mateusz (2018) The Aesthetics of Garden Conservation, "Aesthetic Investigations” [forthcoming].

Seel, Martin (2009) Eine Ästhetik der Natur, Frankfurt am Mein: Suhrkamp.

Spaid, Sue (1995) Open Systems: Incompleteness, Participation, and Elasticity. Exhibition Brochure. Santa Monica: Santa Monica Museum of Art.

Spaid, Sue (2002) Ecovention: Current Art to Transform Ecologies. Cincinnati: Contemporary Arts Center.

Spaid, Sue (2017) Ecovention Europe: Art to Transform Ecologies. Sittard: De Domijnen Hedendaagse.

Taira, Yuichiro (2018) Conserving the Genes of the Arts in Japan, "Aesthetic Investigations" [forthcoming]. 
Van Buren John (2013) Environmental Hermeneutics. Deep in the Forest, [in:] F. Clingerman, B. Treanor, M. Drenthen, D. Utsler, eds., Interpreting Nature: The Emerging Field of Environmental Hermeneutics, New York: University Press, pp. 17-35.

\section{ESTETYCZNE I MATERIALNE IMPLIKACJE PARTYCYPACYJNE- GO CHARAKTERU EKOWENCJI (streszczenie)}

W artykule pod mianem dzieła partycypacyjnego rozumiemy takie dzieło, które jest stworzone przez pojedynczego artystę lub w skutek kolektywnego działania i które zaprasza uczestników (odbiorców) do tego, by zmieniali jego wygląd, strukturę i/lub funkcję, zachowując przy tym jego cel. Tak pojęta partycypacja jest szczególnie istotna w przypadku „ekowencji” (termin zaproponowany przez Sue Spaid), czyli inicjowanych przez artystów praktycznych działań mających na względzie kwestie ekologiczne. Najogólniej rzecz ujmując, ekowencje to prace, których głównym celem jest poprawienie sposobu funkcjonowania określonego ekosystemu. W naszym przekonaniu tego rodzaju projekty - z racji ich artystycznego charakteru - oraz praktyki z nimi związane mogą skutkować ze strony publiczności estetycznym doświadczeniem środowiska zasadzającym się na poczuciu uczestnictwa w ekosystemie. W naszym przekonaniu ekowencje jako dzieła sztuki partycypacyjnej są ważne, ponieważ poszerzają pole sztuki o kwestie środowiskowe oraz o nowy model partycypacji, a także mogą skutecznie przyczynić się poprawy ekologicznych walorów określonych miejsc.

Słowa kluczowe: Ekologia, ekowencja, estetyka, partycypacja, środowisko 